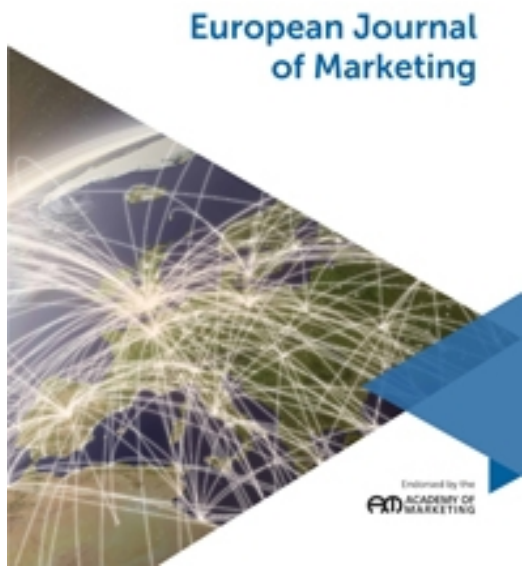

The Long-Term Erosion of Repeat-Purchase Loyalty

\begin{tabular}{|r|l|}
\hline Journal: & European Journal of Marketing \\
\hline Manuscript ID & EJM-01-2018-0042.R4 \\
\hline Manuscript Type: & Original Article \\
\hline Keywords: & Brand Loyalty, Erosion, Repeat-Purchase, NBD model \\
\hline \multicolumn{2}{l}{} \\
\end{tabular}

SCHOLARONE $^{\text {Im }}$ Manuscripts 


\title{
The Long-Term Erosion of Repeat-Purchase Loyalty
}

\begin{abstract}
Purpose. The study investigates the long-term erosion of repeat-purchase loyalty among consumers who purchase brands in a one-year base period.
\end{abstract}

Design/Method. The study utilises a five-year consumer panel of continuous reporters. We identify brand buyers in a base year, then calculate the proportion that fail to buy the brand in later years. We analyse the top 20 brands in 10 consumer goods categories.

Findings. We find pronounced erosion in repeat-buying over the long-term. The proportion of buyers from a base year that fail to buy the brand in a later year increases steadily over time, from $57 \%$ in year 2 to $71.5 \%$ by year 5 . Moreover, we identify brand and marketing mix factors linked to this over-time customer loss, or erosion.

Research Implications. The study provides evidence that consumers' propensity to buy particular brands changes over a period of years, even though those brands continue to exhibit stable market share. This evidence provides a different interpretation than the literature to date, which has viewed purchase propensities as fixed.

Practical Implications /limitations. The study finds that store brands and niche brands exhibit lower levels of erosion in their buyer base; that a broad range is associated with lower erosion, and that high price promotion incidence is associated with lower erosion for manufacturer brands.

Originality/Value. Loyalty erosion has been reported before (Ehrenberg, 1988; East \& Hammond 1996) but only over short periods. This study examines the phenomenon over five years, confirms that the rate of erosion does diminish over time, and that it is related to category and brand characteristics, as well as marketing mix decisions.

Keywords: repeat-purchase, loyalty, NBD model, erosion 


\section{Introduction}

In developed economies, most packaged consumer-goods brands compete in categories characterized by stable, split-loyal brand buying (East et al., 2008). Under these conditions, many brands have stationary metrics over periods such as a quarter-year or year. That is, the brand's market share, penetration (\% buying) and loyalty (average number of purchase occasions per period, share of category requirements) from one quarter to another or one year to another are quite stable. Furthermore, those metrics such as penetration and loyalty can be estimated with a high degree of accuracy by the NBD-Dirichlet model (Ehrenberg et al., 2004), using only category-level information and brand market shares. Another important brand metric is the proportion of one period's buyers who return to buy the brand in the next period. This we term the repeat-rate (Ehrenberg, 1988). Again, the NBD-Dirichlet estimates the repeat rates for brands with a high degree of accuracy (Fader and Schmittlein, 1993); usually for one-period ahead forecasts such as next quarter or year. The model assumes stable long-term buying propensities (Goodhardt et al., 1984), which matches well with the stability in market shares exhibited by many brands (Dekimpe and Hanssens, 1995a, Graham, 2009). However, several pieces of research have shown that the repeat-rate declines as one looks further forward in time from a base period (East and Hammond, 1996, Ehrenberg, 2000). For example, the proportion of base period 1 buyers who re-buy in period 2 drops in period 3 and again in 4 and 5, and so on. This decline has been termed erosion. The surprising fact about erosion is that it occurs for stable brands - the brands that have been studied maintain their overall market share, penetration and purchase frequency despite erosion in their initial buyer base.

While it is obvious that to maintain market share, these stable brands are replacing eroded or 'lost' buyers with new ones, the loss of base period customers is an important phenomenon to 
investigate. First, in order to maintain their market share, brands are replacing lost buyers this maintenance would be easier to accomplish if it were possible to reduce the rate of erosion, because fewer 'new' buyers would be needed to top up the loss. However, it is as yet unknown if some brands have a superior ability to dampen their erosion rate - apart from the fact that brand size negatively correlates with erosion, as per East \& Hammond (1996). Identifying if there are brand characteristics that are linked to lower or higher erosion rates would have practical as well as theoretical significance. Additionally, it is also not known if there are marketing mix elements (price, promotion, new products) that might reduce the erosion rate; nor indeed if erosion continues over the long term. Knowing how these aspects influence erosion would enable managers make better decisions how to deal with it.

East \& Hammond (1996) found the rate of erosion slowed down after four quarters but did not look further than 18 months. It is not presently known if the rate continues to slow, and consequently how significant the problem of erosion is over multiple years. There is a growing recognition of the importance of a long-term view of brand building (Ataman et al., 2008, Lodish and Mela, 2007), therefore an investigation of erosion in the customer base over multiple years will contribute to the literature on effective management of brands.

Next, in a stationary category, if a brand's initial buyer base is drifting away over time, those customers are likely buying other brands - but it is not known if erosion manifests as the brand's customer base switching to a tighter assortment of competitors, or to a broader brand repertoire. The contribution of this study is to establish the nature and extent of erosion over the long-term, as well its antecedents and outcomes. The principal questions the study addresses are:

1. Does erosion continue linearly over multiple years?

2. Are there category, brand and marketing mix variables that link to the rate of erosion? 
3. Does erosion in the brand's customer base result in a narrower or broader competitor repertoire over time?

4. What are the implications of erosion for brand management?

We address these questions using a five-year consumer panel of continuous reporters, across multiple product categories. We identify brand buyers in a base year, then calculate the proportion that fail to buy the brand in later years.

In the next section, we review literature on brand repeat-purchase, introduce the erosion concept and why it is important. We develop a series of hypotheses relating to the scale and shape of erosion over multiple years, and a series of factors that are likely to co-vary with it. We explain the nature of a long-term dataset of continuous panel reporters used to test the hypotheses, present the empirical results, and then discuss the implications for theory and practice. Table 1 contextualises the present study with the limited previous work on this issue. 
Table 1. How the present study builds on past work on Erosion

\begin{tabular}{|c|c|c|c|}
\hline & Ehrenberg 1988 & $\begin{array}{l}\text { East \& Hammond } \\
1996\end{array}$ & This study \\
\hline Overall objective & $\begin{array}{l}\text { Identify that erosion } \\
\text { occurs }\end{array}$ & $\begin{array}{l}\text { To identify the } \\
\text { magnitude of erosion } \\
\text { and its shape }\end{array}$ & $\begin{array}{l}\text { To explicate how erosion } \\
\text { manifests in the long term, } \\
\text { identify antecedents and } \\
\text { consequences }\end{array}$ \\
\hline $\begin{array}{l}\text { Time period and } \\
\text { trajectory of erosion } \\
\text { considered }\end{array}$ & $\begin{array}{l}\text { Four quarters. } \\
\text { Change in rate over } \\
\text { time not considered }\end{array}$ & $\begin{array}{l}\text { Eight quarters. } \\
\text { Yes, but limited }\end{array}$ & $\begin{array}{l}\text { Long time frame (five years). } \\
\text { Yes, trajectory considered }\end{array}$ \\
\hline $\begin{array}{l}\text { Number of brands } \\
\text { and categories }\end{array}$ & $\begin{array}{l}\text { Top five brands. } \\
\text { One category }\end{array}$ & $\begin{array}{l}\text { Top five brands. Nine } \\
\text { categories }\end{array}$ & $\begin{array}{l}\text { Top twenty brands. Ten } \\
\text { categories }\end{array}$ \\
\hline $\begin{array}{l}\text { Brand and categories } \\
\text { characteristics as } \\
\text { antecedents / } \\
\text { covariates of erosion } \\
\text { considered }\end{array}$ & No & Yes & Yes \\
\hline $\begin{array}{l}\text { Marketing mix } \\
\text { elements as } \\
\text { antecedents / } \\
\text { covariates of erosion } \\
\text { considered }\end{array}$ & No & No & Yes \\
\hline $\begin{array}{l}\text { Consequences of } \\
\text { erosion considered }\end{array}$ & No & No & $\begin{array}{l}\text { Yes. Marketing implications } \\
\text { are drawn }\end{array}$ \\
\hline $\begin{array}{l}\text { Explanation for how } \\
\text { erosion occurs }\end{array}$ & No & No & $\begin{array}{l}\text { Yes. Explanation relates to } \\
\text { drift in purchase propensities } \\
\text { over time }\end{array}$ \\
\hline
\end{tabular}




\section{Background and Literature Review}

It should almost go without saying that repeat-purchase loyalty is an important marketing metric. At its most obvious, the 'sales equation' for a brand is: (adapted from Uncles and Ellis, 1989) Brand unit sales $=$ Number of brand buyers $x$ average purchase frequency $x$ average units per occasion. On-going brand sales are therefore highly contingent on maintaining an acceptable level of repeat purchasing across a buyer base. Next, repeatbuying loyalty makes for more certainty about the future of the brand, as it implies buyer satisfaction (Kumar et al., 2013). And indeed, a further sale made to a current buyer is said to be easier than finding a new buyer (e.g. Reichheld, 1993), although this axiom is more of an intuitive belief than empirical fact (Sharp, 2010 p. 29).

Given the importance of loyalty, it is not surprising that many conceptual and empirical models have been constructed to understand, measure and explain it over the past sixty years. We focus first on behavioural loyalty and discuss a stochastic model widely used to predict repeat-purchase rates. We then discuss the phenomenon of erosion, and describe it from a strictly behavioural viewpoint before considering how an attitudinal viewpoint can also help in understanding it. From this discussion, we formulate a series of hypotheses relating to erosion, as well as factors that are related to lower or higher levels of erosion. We then test the hypotheses using a long-term panel of continuously-reporting households.

Commencing in the late 1950's, researchers discovered empirical patterns in brand performance metrics such as market share, penetration, and various behavioural loyalty indicators such as purchase frequency and share of category requirement (SCR). First was that category purchase rates followed a Negative Binomial Distribution or NBD (Ehrenberg, 1959). Brand purchase rates were shown to follow the same pattern (Ehrenberg, 1988), and also that there was a systematic relationship between indicators of a brand's size (market 
share or penetration) and loyalty: the famous double jeopardy pattern (Ehrenberg et al., 1990). Furthermore, the extent to which buyers of one brand also purchase others was found to closely follow the penetration levels of each brand (Ehrenberg, 1988) in a category. These empirical patterns or regularities form part of an integrated model of buyer behaviour and brand performance called the Dirichlet (Ehrenberg et al., 2004), of which a central part is the NBD. We briefly elaborate on the NBD.

\subsection{The NBD}

The NBD was introduced into marketing literature by Ehrenberg over fifty years ago (1959). The model assumes that individual propensities to buy a category or brand are fixed, distributed Gamma over the population, and that individual brand purchase incidence will follow an as-if random Poisson distribution over time. Mixing the two gives an NBD, or negative binomial distribution. The NBD describes the distribution of brand purchase frequencies $0,1,2,3, \ldots . n$ across the population in a specified period. For consumer goods, this distribution invariably takes the form of an 'inverse J', with a very large number of purchasers buying infrequently, for example 1 or 2 times per year, far fewer buying 3 or 4 times, and a long tail of very few households buying more frequently. Many marketing applications of the NBD have been reported in the literature including consumer packaged brands and categories (Chatfield et al., 1966, Dawes, 2014, Ehrenberg, 1988, Ludwichowska et al., 2017, Trinh, 2014, Tanusondjaja et al., 2016), gambling products (Mizerski et al., 2004, Lam and Mizerski, 2009), consumption of mobile phone service (Lee et al., 2011), cultural venue and event attendance (Trinh and Lam, 2016), and industrial purchasing (McCabe and Stern, 2009, Wilkinson et al., 2016).

The NBD is also able to accurately estimate the proportion of period 1 households who buy a brand $0,1,2,3 \ldots . n$ times that will buy it $0,1,2,3 \ldots . n$ times in period 2 (Goodhardt and Ehrenberg, 1967). This feature of the NBD model is called Conditional Trend analysis 
(Morrison, 1969, Lenk et al., 1993, Habel et al., 2003). It highlights that even though a brand's penetration in aggregate usually remains constant from period to period, the actual mix of households and the rate at which they buy varies from period to period. Importantly, the NBD specifies that for a stationary brand, the proportion of repeat buyers from one period to another will be the same regardless of whether it is measured from an adjacent or nonadjacent period, even if those periods are years apart.

\subsection{The Leaky Bucket-Erosion}

In Repeat Buying (1988, p47) Ehrenberg reported a deviation from the NBD-expected levels of repeat purchase, described as the 'leaky bucket'. The study compared the proportion of brand buyers in an initial quarter (Q1) that repeated in the next (Q2) with its NBD estimate, and then increased the time lag of the repeat-buying observations from Q1 to Q3, and from Q1 to Q4. There was a drop of four points in the proportion of buyers repeating from Q1 each time. This figure translated to a decay of $6.5 \%$ in repeat purchase loyalty for each quarter beyond a base period. East and Hammond (1996) replicated and extended Ehrenberg's initial analysis. This study examined a longer time period using nine product categories. It found erosion reached an average 15 percentage-point loss in a year, even though quarterly brand penetrations were stationary. Several other findings emerged. First, large brands had lower erosion rates than small brands, and erosion was consistent across light, medium and heavy buyers. Notably, the study found no co-variation with other factors such as purchase frequency, country, category, or market concentration. Erosion was therefore described as "a consistent pervasive empirical fact that is little related to the other factors studied." (p. 169). East and Hammond also reported that the rate of erosion slowed after the first year.

This erosion of loyalty among buyers from a base period is worthy of further study for several reasons. In simple terms, erosion means a brand is 'losing' customers from a base period 
over time. Given the intense interest in customer loyalty and retention (e.g. Evanschitzky et al., 2017), further understanding of erosion has theoretical and practical importance. Firstly, clarifying if the rate of erosion does indeed decline as found by East \& Hammond (1996) will help us to understand the extent to which it poses a challenge for marketers. Second, the NBD, a widely-used stochastic model, assumes fixed purchase propensities (Sharp et al., 2012). More insights into long-term erosion may provide a different interpretation. Indeed, further understanding of erosion will increase our knowledge about how consumer's brand purchase propensities evolve over time. For example, if there is indeed erosion over the long term, it could conceivably manifest in smaller brand repertoires among the brand's initial base period of buyers, consistent with them merely dropping the focal brand. An alternative is that erosion coincides with a larger, expanded repertoire among those initial buyers - one brand is dropped, one or more enters the repertoire.

Next, from a practitioner viewpoint, while brands appear to maintain their market share despite erosion occurring, it may be the case that some erode less than others over time. While there is evidence that brand growth arises more from superior acquisition of new buyers than retaining existing ones (e.g. Riebe et al., 2014), an enhanced ability to retain last year's buyers makes maintenance or brand growth an easier task. Identifying factors that covary with erosion may give guidance for managers interested in remediating the problem. The study considers how price promotions (Bogomolova et al., 2015), niche brand (Bhattacharya, 1997), brand type - store brand or manufacturer brand (De Wulf et al., 2005), the brand's price level (Sethuraman and Srinivasan, 2002) and range breadth (e.g. Tanusondjaja et al., 2018) are associated with lower or higher levels of erosion. The outcome of erosion in terms of brand repertoire change over time is also examined. 


\subsection{Potential reasons for Erosion}

Given that brands often have stable market share, it is not necessarily obvious how erosion occurs. But what it suggests is that some consumers' propensities to buy brands alter over time. The simplest explanation is that marketing activity for brands is noticed, and in addition to reinforcing and reminding existing buyers (Ehrenberg et al., 2002), it has a customer acquisition effect: as a result of the marketing stimuli, some consumers add the brand to their repertoire and therefore have less need of another brand they previously bought. Another potential explanation is variety seeking (Kahn, 1995, McAlister and Pessemier, 1982), whereby some consumers simply wish to try a different brand, one they have not purchased before or for a long time period. Such a purchase may result in some positive purchase reinforcement (Givon and Horsky, 1990, Kahn et al., 1986), thus the household may add it to their longer-term repertoire.

To this point, the discussion about loyalty and loyalty erosion has principally been from a strictly behavioural perspective, but the loyalty literature also canvasses attitudinal loyalty. Indeed, many authors in this area discuss the idea of true loyalty, requiring a combination of high levels of purchasing and positive brand attitudes (Dick and Basu, 1994). Apparently, however, only a minority of brand buyers, in the order of $10 \%$ or less, meet these criteria (Baldinger and Rubinson, 1996, Bandyopadhyay and Martell, 2007). Low levels of 'true' loyalty appear consistent with the fact that consumers typically buy from repertoires of several brands in a category. Multi-brand buying makes the incidence of heavy brand buying somewhat less common, and it would be paradoxical for a consumer to have very positive attitudes about multiple brands in a category. However, this pattern of most buyers having fairly low 'true' loyalty may actually be consistent with the studies of erosion to date. Given that, as per Baldinger \& Rubinson (1996) and Bandyophadyay \& Martell (2007), most brand 
buyers are apparently not strongly attitudinally attached to a brand, it would not be difficult for some to down-weight their purchase propensity for the brand over a time period of several years, i.e., to erode. By contrast, the brand buyers who are more attitudinally loyal may be more likely to remain in the brand's long-term base. Some potential evidence for the role of attitudes in limiting loyalty erosion comes from Baldinger \& Rubinson (1996), which found that prediction of a brand's purchase rates in year 2 was superior using a combination of year 1 purchasing and attitudinal information than from year 1 purchasing data alone. This finding suggests that attitude may be causally implicated in directing future behaviour; and that stronger attitude is linked to higher future purchase. However, it may also be the case that the attitudinal scores actually reflect long-run brand purchasing propensity, which would help account for the fact that in any given time period, the observed brand purchase rate can fluctuate around its longer-term level ${ }^{1}$ (Schmittlein et al., 1993).

Erosion may also be realistically understood from a consumer based brand equity perspective, particularly in relation to memory structures. Consumers form beliefs and perceptions about brands from experience and exposure to marketing communications. Consumers' ability to retrieve these perceptions from memory has been found to be quite variable over time, with research finding that only around $50 \%$ of those that agree a brand has a given characteristic, or is suitable for a particular usage situation, will do so again when re-surveyed (Castleberry et al., 1994, Dall'Olmo Riley et al., 1997). Therefore, it may be the case that some consumers happen to not see or notice marketing communications for a brand they normally buy, accidentally forget to buy it, or it simply fails to 'come to mind' in a buying situation. The outcome is that a different brand to one in the normal repertoire is bought, the original brand

\footnotetext{
${ }^{1}$ For example, a household might usually buy a brand six times per year but just happened to buy it only twice in one specific year. Its attitudinal score for that brand at the time might more fully reflect its usual purchase behaviour and so appear 'predictive' of the return to the normal buying rate of around six times, in year 2.
} 
loses its place in the consumer's repertoire, and may perhaps not be bought again for years afterwards. This process of customer churn occurs to some extent for all brands in a category, and yet brand shares maintain equilibrium over time. Unfortunately, the present study does not have access to attitudinal or brand awareness/mental availability data, therefore further investigation of the role of these factors in erosion is outside its scope.

In the next section, we identify category and brand characteristics as well as several marketing mix variables that logically link to erosion levels. These form the basis of a series of hypotheses.

\section{Hypothesis development}

\subsection{Extent of Erosion over multiple years}

Ehrenberg (1988) reported an erosion rate of approximately $6 \%$ per quarter, but the analysis was limited to a 12-month period. East and Hammond (1996) reported an erosion rate of $15 \%$ per year, but also found the rate of erosion flattened in the second year. We now consider the possible shape of erosion over a longer timeline. There are two factors to be considered. First, it is logical to think that base-period buyers with weaker memory structures (or perhaps lower levels of positive attitude) relating to the brand might erode earlier, leaving a progressively more positive or more memory-prominent cohort. This implies erosion should slow as the time period lengthens between the base year and the subsequent year in which we observe re-purchase. However, a longer elapsed time period from the base provides more opportunity for change in tastes to occur (e.g. Swait and Adamowicz, 2001), therefore the rate of erosion might accelerate. For example, more of the base might erode between year 3 and 4 than between year 2 and 3. These two factors may result in mutual cancellation of effects. Therefore, we hypothesise: 
H1. Erosion in the brand's base period buyer base occurs at a constant rate over multiple years.

\subsection{Repertoires}

Next, we consider how erosion might influence the evolution of consumer repertoires. There is evidence that consumer brand repertoires get larger over longer time periods such as from a quarter to a year (Banelis et al., 2013), or longer (Trinh, 2014). A relevant question for this study is, if we observe a cohort of brand buyers that exhibits erosion, how will that erosion be reflected in terms of the accumulated growth in those buyers' repertoires over time. One possibility is that repertoire growth is slower than expected. This could happen because those buyers that erode away do not tend to replace that 'lost' brand in their repertoire. However, it may be the case that, due to erosion, repertoires grow more than would be expected. The reason is because brands often exhibit aggregate level equilibrium in sales and market share over multi-year periods (Dawes et al., 2015, Dekimpe and Hanssens, 1995a). If brands are stable in the aggregate, yet have buyer bases that are eroding, they are simultaneously topping up the eroded buyers with new ones. This in turn means that cumulative buyer repertoires will be larger than they otherwise would be. Another way of conceptualising this scenario is that for any brand, it and its competitors have buyer bases that are eroding, so there is overall more mobility in the consumer base across all brands. However, a theoretical benchmark is needed to determine the size of brand repertoires after five years if there were no erosion. The NBD model, which assumes constant purchase propensities and therefore no erosion, provides such a theoretical benchmark (East and Hammond, 1996, Trinh, 2014). Accordingly,

H2. Buyer repertoires over a multi-year period will be larger than predicted by the NBD model. 


\subsection{Incidence and depth of promotion.}

Temporary price promotions attract existing brand buyers (Ehrenberg et al., 1994) as well attracting some switchers who primarily buy other brands. Given that price promotions are very prevalent (Ataman et al., 2010) yet brand repertoires are quite small, i.e. 2-3 brands in an annual period (Banelis et al., 2013), promotions are likely to primarily appeal to existing brand buyers. Recent empirical support for this conclusion was reported in Dawes (2018). The theoretical mechanism is that a brand is recognisable and familiar to its own buyer base (Ambler et al., 2004), and a promotion offers consumers the chance to buy a brand they already have a high probability of buying, via enhancing evaluation (Grewal et al., 1998) and value perceptions (Zeithaml, 1988). Price promotions also draw attention to the brand to those who do not normally buy it, however, the focus of this study is erosion of the brand's existing buyer base. Based on these points, higher promotion incidence should help retain the brand's buyer base by offering it periodic opportunities to buy it at a reduced price, hence retarding migration to competitor brands.

H3a. High promotion incidence for a brand is negatively related to erosion.

It would be useful to identify if the effect of promotion incidence on erosion is different for manufacturer brands compared to store brands. Past work does not provide clear guidance for a hypothesis in this regard, for example Bijmolt, van Heerde and Pieters (2005) finds nonsignificant differences in price response for store brands compared to manufacturer brands. Therefore, we do not formulate a specific hypothesis in this regard, but in our regression model we create an interaction term for brand type and promotion incidence to examine this potential difference.

A point related to $\mathrm{H} 3 \mathrm{a}$ is that consumers may be exposed to price promotions for several of the brands they buy in a category; and some of those brands may offer deeper price cuts than 
others. One viewpoint, as suggested by the reference price literature, is that deep price cuts lead consumers to form a lower reference price for the brand (Kalwani et al., 1990, Lattin and Bucklin, 1989). This will arguably have a negative effect on re-purchase during nonpromotion periods, and therefore also lead to heightened erosion. However, empirical work indicates little in the way of negative buyer behaviour after-effects from price cuts (Ehrenberg et al., 1994). The alternative viewpoint is that brands endeavour to preserve their buyer base in the face of price-cutting by competitors, and deeper cuts offer more perceived value to consumers (Alford and Biswas, 2002). Therefore, a brand offering on-average deeper price cuts will likely retain its buyers compared to a brand offering shallower ones. Therefore,

H3b. Depth of price cuts for brand price-promotions is negatively related to erosion ${ }^{2}$.

\subsection{Niche brand.}

Niche brands have high loyalty for their market share (Bhattacharya, 1997). Bhattacharya suggests that this high loyalty is due to the brand accommodating the needs of a specific market segment. Kahn et al suggests a niche brand is catering to a specific need (Kahn et al., 1988). These points suggest that a niche brand is somewhat less substitutable than other competing brands in the market, and so buyers would find it more difficult to replace the brand in their repertoire. Relatively high loyalty can also be due to localised presence in geographies or channels (Pare and Dawes, 2011) - such brands may be highly salient or wellknown in the selected places they are available. These points suggest the rate of erosion should be lower for brands that have more pronounced niche characteristics.

\footnotetext{
2 In theory there is a third potential measure of promotion, namely breadth - the proportion of a brand's range of items that is promoted, which unfortunately we are unable to calculate. This measure would require information on the weekly promotional status of every SKU in each brands' range within every retailer. This level of detail is not available in the supplied datasets. We mention the use of this measure as an avenue for further work.
} 
H4. The extent to which a brand is niche (relative to other brands in the category) will be associated with a lower rate of erosion.

\subsection{Store Brands.}

Manufacturer brands are generally sold in the stores of multiple retailers. Retailers also sell their own store brands, and have control over shelf space and in-store communication to promote these brands (e.g. Hyman et al., 2010, Nogales and Suarez, 2005). This control may result in a greater level of in-store salience for store brands, thereby helping to retain buyers and so slowing the extent of erosion. Also, store brands are often present across many categories (Sayman and Raju, 2004) although some retailers such as Aldi use a multiplicity of store brand names. Many households are likely to buy a retailer-named store brand from at least one category on many shopping trips. There is some limited evidence in the literature of positive, albeit weak, purchase feedback effects (Allenby and Lenk, 1995, Keane, 1997), and so buying a store brand in one category could potentially re-inforce the purchasing of that same brand, in a different category. This wide cross-category presence of store brands may therefore have a dampening effect on erosion. Also, while store brands are no longer strictly low-price, lower-quality offerings, they may still appeal to consumers with a 'value trait' (Seenivasan et al., 2015) which may help preserve their buyer base over time. Therefore,

H5. Store brands will have lower rates of erosion.

\subsection{Low-price brands.}

Studies indicate that buyers of lower-priced brands exhibit greater purchase loyalty to them (Bhattacharya et al., 1996, Dawes, 2013, Jung et al., 2010). A theoretical rationale relates to what is called the asymmetric price effect (Sethuraman et al., 1999) between high price and low-price brands. That is, when high-price brands price-promote they make the brand 
temporarily more affordable to low-price brand buyers, who therefore occasionally 'switch up'. This switching-up inflates the high-price brand's penetration, but because it is only occasional, diminishes the higher priced brands' repeat-purchase loyalty. By contrast, when low-priced brands price-promote they do not attract much 'switching down' from high-priced brand buyers, because those buyers perceive a large quality difference (Sethuraman, 1996). The upshot is that the buyer base of low-priced brands comprises buyers who buy low-price more consistently, whereas the buyer base of high-priced brands includes a larger proportion of occasional (low-price) switchers. A second rationale is that certain buyers are more pricesensitive, perhaps linked to demographics such as household size (Hoch et al., 1995). Such buyers may confine their purchases to lower-priced brands (Sethuraman and Cole, 1999), which increases the purchase loyalty of those brands. It is a reasonable proposition that if low-priced brands enjoy higher loyalty, this will translate to lower customer loss or erosion over time. Accordingly,

H6. Low brand price, relative to the category average, will be associated with lower erosion.

Note that $\mathrm{H} 5$ pertains to store brands and H6 relates to low brand price. The question may arise as to whether low brand price is a characteristic closely associated with store brands. While store brands have traditionally been low-priced competitors (Kumar and Steenkamp, 2007), in many cases they now offer comparable quality and price to national brands (ter Braak et al., 2014). In a subsequent section we show that the variables of low price and store brand are sufficiently distinct for the analysis.

\subsection{Large range.}

A large range of line items may help a brand appeal to both existing and non-buyers, preserve or win shelf-space (Tanusondjaja et al., 2018), and demonstrate category leadership to retail channels. A large range may also act to retain buyers over time. There is less motivation to 
cease using a brand if it offers a very wide range of options (e.g. Kahn, 1995). Indeed, Tanusondjaja, Trinh and Romaniuk (2016) found that new variants tend to be purchased by buyers of the parent brand, suggesting they play a role in retention. Therefore, if a brand's range (measured as number of line items) is larger, erosion should be lower. Accordingly, H7. A larger brand range, relative to the category average, will be associated with lower erosion.

\subsection{Brand Size (penetration), Category Purchase rate and category penetration.}

Larger brands, that is, brands with higher market share and penetration, are known to have higher loyalty (Ehrenberg et al., 1990, Dawes et al., 2017). East \& Hammond (1996) also found they had lower erosion rates. Since this relationship is already known, we do not include a hypotheses relating to brand size, but we include it in the model to avoid omitted variable bias (Greene, 2011 Ch.8). We also include category purchase rate, as did East \& Hammond (1996). We also include category penetration, which has been linked to brand loyalty on the basis that larger categories have a greater number of infrequent users with lessformed preferences (Casteran et al., 2019).

\section{Data and Method}

Household panel data were provided by Kantar. The Kantar UK panel comprises approximately 35,000 households. In order to evaluate long-term erosion and to avoid confounding erosion with panel attrition, a sub-sample of 12,400 continuous reporters over 5 years was extracted. The sub-sample comprised only households who reported purchases over the entire time period.

A question arises as to whether the long-term panelists might be intrinsically more loyal (since they stay in the panel for many years); which could bias the estimation of erosion 
downward. To check if this was the case, we compared the loyalty of the long-term panelists in the fifth year, to that for the entire panel (which includes those who dropped out) in the first year. If the long-term panelists have some intrinsic loyalty proneness or have become habituated from reporting, then loyalty in the fifth year (among the long-term panelists only) should be higher than what we see from the entire panel in the base year. For this comparison we used annual Share of Category Requirements or 'SCR', a commonly used loyalty metric (Farris et al., 2016). Higher SCR indicates higher behavioral brand loyalty, and is more comparable across categories than other measures such as brand purchase frequency. We found average Share of Requirements allocated to each brand (over the top 20 brands in our 10 categories) to be $26 \%$ in year 1 panel-wide, and $25.5 \%$ among the long-term panelists in year $5(\mathrm{t}=1.2$, df $199, \mathrm{p}=0.22)$. Therefore, the long-term panelists do not exhibit higher behavioral loyalty compared to panel members generally, and so the estimates of erosion should be unbiased.

We use ten diverse consumer packaged goods categories to ensure reasonable generalizability of results. The categories are subsequently detailed in Table 2.

The two prior studies upon which this study builds (Ehrenberg 1988, East \& Hammond 1996) used brands with stable market shares. We do the same. A study of brand share stability (Graham, 2009) used a threshold of 3 percentage point change over five years. We use a stricter criterion of 2 percentage point change over the period ${ }^{3}$. We also show an analysis that uses all brands, i.e. including those that grew or declined by more than 2 points for comparison. This supplementary analysis produced very similar results.

\footnotetext{
${ }^{3}$ We also selected stable brands by regressing year 1 market share on year 5 market share, calculating standardized residuals and selecting only those brands with a residual between $+/-1.96$, i.e. brands for whom the difference in year 5 market share was non-statistically significant at $p<=0.05$. The results are invariant to this criterion, compared to the 2-point change criterion.
} 
We used the top 20 brands in ten categories, to avoid confounding effects from brands with very small numbers of purchases (Pare and Dawes, 2011). These brands accounted for $84 \%$ market share on average $(\min .=72 \%$ ) in each category, and feature in the data across the entire five years. Therefore, we have an inclusive and representative sample of brands, and in a diverse variety of categories including food, personal care and household goods.

To investigate the occurrence of erosion, we first identified all the households who purchased a brand in the base year. We use a one-year period, whereas Ehrenberg (1998) and East \& Hammond (1996) used quarters. The reason for using a year is that it results in a larger number of buyers for all brands, making the comparisons between base and the later years more accurate. A one-year period also eliminates potential seasonality effects that might arise using quarters.

After identifying the households who purchased a brand in the base year, we then identified the proportion of those households who did not purchase that brand in the second year, i.e., one year on from the base. We continued this process to identify the proportion of base-year (year 1) buyers who did not purchase the brand in year 3,4 and 5; in other words, the progressive loss of the brand's base year customers. In each case we examine one-year windows that progressively get further away from the base year.

We then calculated from the Kantar data annual observations for the suite of brand and category characteristics used as independent variables. We consequently have observations for 200 brands over a four-year period from the base year, for a total of 800 observations. The measures used in the analysis are now outlined.

\section{Measures.}

Customer Loss (the dependent variable). 
Proportion of base year (year 1) brand buyers that fail to re-purchase brand in year 2, 3, 4, 5. The accumulation of this customer loss over time is erosion (based on East and Hammond, 1996). Variable type: metric.

\section{Repertoire Size.}

Average number of brands bought (Banelis et al., 2013) in each category by its buying households, over the five-year period. This is calculated by summing the total number of different brands bought in the base year, and cumulatively over five years, by buyers in each of the 10 categories. For example, the average repertoire size in the fabric care category in the base year is 2.4 brands, over the five years it is 4.3 brands. This variable is used to test $\mathrm{H} 2$, and is not included in the regression model. Variable type: metric.

\section{Independent variables.}

\section{Promotion incidence and depth.}

This variable is the proportion of each brand's sales sold on promotion (Scriven et al., 2017) in each year. We index this measure and others relative to the category average (e.g., Macé and Neslin, 2004, Jung et al., 2010) to avoid confounding the analysis results with category level differences in variables such as promotion, price levels or range breadth. Variable type: metric.

\section{Promotion depth.}

Average depth of each brand's price-promotion discount depth, for each year (Bogomolova et al., 2015), indexed to the category average. Variable type: metric.

\section{Niche brand.}


This variable is brand purchase frequency compared to the formula $\left(\mathrm{w}_{\mathrm{i}}\left(1-\mathrm{b}_{\mathrm{i}}\right)\right)($ Bhattacharya, 1997, Kahn et al., 1988). We first calculate the proportion of households that buy each brand in each year. We then calculate the average number of occasions those buyers buy each brand in each year. In the formula $\left(\mathrm{w}_{\mathrm{i}}\left(1-\mathrm{b}_{\mathrm{i}}\right)\right), \mathrm{w}_{\mathrm{i}}$ denotes brand purchase frequency and $\mathrm{b}_{\mathrm{i}}$ denotes brand penetration. Substituting each brand's actual penetrations and purchase frequency produces a figure that is approximately constant for brands in a category, in line with the double jeopardy pattern (Graham et al., 2017). We take the average of the constant. We then subtract the actual purchase frequency of each brand in the category from this constant. Figures above the constant indicate the brand is 'niche' - purchased more frequently than expected, for its market share. Figures below the constant indicate the brand is 'change of pace' - purchased less frequently than expected, for its market share. Kahn et al (1988) also provides detailed calculations. Variable type: metric.

\section{Store brand.}

Retailer's own brand, sold only in that retailer (Pare and Dawes, 2011). Store brand is indicated with a 0,1 code $(1=$ Store brand), for each brand, in each year of the data. This is a time-invariant variable, whereas all the other variables take different values across years. Variable type: binary.

\section{Low-priced brand.}

We calculate each brand's non-promoted price relative to the category average for each year in the data. Prices are price per unit of weight to control for pack size differences across brands. Previous examples of this measure are Bolton (1989); Mace and Neslin (2004) and Keller \& Deleersnyder (2019). Variable type: metric.

\section{Range breadth.}


Number of variants offered by the brand in each calendar year (Tanusondjaja et al., 2018). This is calculated by observing the number of line items of each brand with non-zero sales within each year. This measure is then indexed relative to the category average. Variable type: metric.

\section{Brand penetration.}

We calculate the proportion of panel households that purchase each brand in each year. We then index this measure relative to the category average. Variable type: metric.

\section{Category purchase rate.}

This is the mean average number of occasions the category is purchased per year (Dawes et al., 2015). Note, median was also used as a robustness check and did not alter the results. The distribution of category purchase occasions fits the NBD well, with a MAPE of 0.09 on average (Table 2). This variable is used as a covariate to control for the possibility that erosion for brands in a category is associated with the frequency with which that category is purchased. Variable type: metric.

\section{Category penetration.}

Proportion of panel households that purchased the category in each year. This variable is used as a covariate to control for any association between erosion and category penetration. Variable type: metric.

Descriptive results and a correlation matrix of these variables are presented as an Appendix. 
A question arises regarding the Store Brand variable, and whether it might be highly related to certain other variables such as price. We report the correlations between all variables in the Appendix. Store brand is indeed correlated with several other independent variables at up to moderate levels of approximately $\mathrm{r}=-0.5$. However, we calculated the VIF indicator of collinearity for Store Brand to be 3.1, which is far below the level of 10.0 considered problematic for regression (Hair et al., 1995 Ch. 4). The maximum VIF in the model was 3.6, for promotion incidence.

\section{Analysis model}

We employed a panel data ${ }^{4}$ regression in Stata using the xtreg procedure to test the hypotheses. This model is ideally suited for longitudinal data of the type employed in this study (e.g., Cameron and Trivedi, 2010).

Note that certain brands, in particular retailer brands such as Tesco and Tesco Value, Asda and Asda Smartprice, Sainsbury and others are present in multiple categories. This introduces a lack of independence across observations for these brands that could deflate standard errors and lead to biased estimation (e.g. Greene, 2011 ch.11). Therefore, we coded brands that appeared across multiple categories with the same code (i.e., all Tesco coded as Tesco, all Asda coded as Asda and so on). We specified robust clustered errors for the analysis using this coding scheme. We specified that the model errors were double-clustered by brand and year, to accommodate both sources of dependence across observations.

We checked that the model results were not sensitive to the large number of observations for some of the large retailer brands by running subsets of the dataset, omitting each one in turn.

\footnotetext{
${ }^{4}$ In this context the term panel data refers to repeated cross-sectional observations, in this case of brands.
} 
That is, running the model without Tesco, replacing Tesco and omitting Asda, and so on. The sign and magnitude of the model parameters stayed extremely stable. This checking provides confidence the results are not biased by the presence of the retailer brands across multiple categories. We also ran the models omitting one category at a time, and again the sign and magnitude of the parameters were consistent, indicating the results are not driven by idiosyncratic results from one category.

A potential concern arises about endogeneity, either from omitted variable bias or possibly reverse-causality, such as marketers reacting to erosion by altering their marketing mix. An indicator of endogeneity is correlation between the independent variables and the error term (e.g. Wooldridge, 2015 Ch. 4). We confirmed that the error term was uncorrelated with the independent variables. We then tested for reverse causality by examining if changes in price promotion incidence and product range breadth were related to erosion levels in the previous year. There was no correlation between these variables and past erosion. This provides some confidence that there is not reverse causality present. We do, however, recognise that we do not have information on the full spectrum of marketing activity, such as advertising, to fully rule out endogeneity. We discuss this limitation in the final section.

We used dummy-variable binary coding for the year variable (with year 2 being the contrast year) to incorporate potential non-linear effects of time on erosion. Using a mix of metric and binary independent variables is a conventional approach in regression modelling, for example Greene (2011 Ch. 11) employs several examples. The model coefficients for year 3,4,5 represent the main effect of time on customer loss.

\section{Findings}

We first show the model-free results averaged across brands within each category, along with some key category metrics. Between year 2 and year 5 the average loss of base-year buyers 
( $\%$ failing to rebuy the brand in a year) increased from $57 \%$ to $71.5 \%$. From this figure we derive the erosion rate of 14.5 points ( $26 \%$ in proportional terms) over three years. Details are shown in Table 2. While the extent of loss among base-year buyers varies, it does not vary hugely. We note that the smallest extent of loss is in Ice-Cream, in which $62.2 \%$ of year 1 's brand buyers failed to re-buy in year 5. The extent of erosion from year 2 onwards is therefore (62.2-50.2) 12 percentage points. The largest extent of loss is in Razor blades, with $85.9 \%$ of year 1 's buyers failing to re-buy by year 5 ; the extent of erosion from year 2 to 5 is 14.3 points on average for brands in this category.

Table 2 Descriptive results for Customer Loss \& Erosion

\begin{tabular}{|c|c|c|c|c|c|c|c|c|c|c|c|c|}
\hline & \multirow[b]{2}{*}{$\begin{array}{l}\text { Cat. } \\
\text { Penetration }\end{array}$} & \multirow[b]{2}{*}{$\begin{array}{l}\text { Cat. } \\
\text { Purch. } \\
\text { freq. } \\
\text { (mean) }\end{array}$} & \multirow[b]{2}{*}{$\begin{array}{l}\text { Cat } \\
\text { Purch. } \\
\text { freq. } \\
\text { (median) }\end{array}$} & \multirow{2}{*}{$\begin{array}{l}\text { NBD } \\
\text { fit } \\
\text { (MAPE) } \\
*\end{array}$} & \multicolumn{4}{|c|}{$\begin{array}{l}\text { Avg. \% of Year } 1 \\
\text { brand buyers who do } \\
\text { not buy brand in: }\end{array}$} & \multicolumn{4}{|c|}{$\begin{array}{l}\text { Accumulated erosion in } \\
\text { absolute } \% \text { points }\end{array}$} \\
\hline & & & & & $\begin{array}{l}\mathrm{Yr} \\
2\end{array}$ & $\begin{array}{l}\mathrm{Yr} \\
3\end{array}$ & $\begin{array}{l}\mathrm{Yr} \\
4\end{array}$ & $\begin{array}{l}\mathrm{Yr} \\
5\end{array}$ & $\begin{array}{l}\mathrm{Yr} \\
2\end{array}$ & $\begin{array}{l}\mathrm{Yr} \\
3\end{array}$ & $\begin{array}{l}\text { Yr } \\
4\end{array}$ & $\begin{array}{l}\text { Yr } \\
5\end{array}$ \\
\hline Ice cream & 90 & 15.6 & 9.5 & 0.04 & 50.2 & 57.3 & 58.9 & 62.2 & $n a$ & 7.1 & 8.7 & 12.0 \\
\hline Instant coffee & 85 & 9.5 & 5.5 & 0.04 & 49.0 & 53.0 & 59.2 & 64.2 & $n a$ & 4.0 & 10.2 & 15.2 \\
\hline Cook-in Sauce & 83 & 13.1 & 7.5 & 0.10 & 50.2 & 56.2 & 61.9 & 65.8 & $n a$ & 6.0 & 11.7 & 15.6 \\
\hline Fabric care & 94 & 7.0 & 5.5 & 0.07 & 49.9 & 56.8 & 62.4 & 65.9 & $n a$ & 6.9 & 12.5 & 15.9 \\
\hline Beer / lager & 52 & 7.3 & 3.5 & 0.17 & 59.6 & 64.7 & 68.9 & 72.0 & $n a$ & 5.1 & 9.3 & 12.4 \\
\hline Pasta sauce & 74 & 10.1 & 5.5 & 0.12 & 56.1 & 62.6 & 68.2 & 72.2 & $n a$ & 6.5 & 12.1 & 16.1 \\
\hline Facial Care & 57 & 5.3 & 2.5 & 0.03 & 60.6 & 66.6 & 70.4 & 73.7 & $n a$ & 6.0 & 9.8 & 13.1 \\
\hline Toothpaste & 90 & 6.4 & 4.5 & 0.09 & 56.7 & 65.8 & 69.9 & 73.9 & $n a$ & 9.1 & 13.2 & 17.2 \\
\hline Olives & 27 & 4.7 & 2.5 & 0.11 & 66.5 & 73.3 & 77.2 & 79.5 & $n a$ & 6.8 & 10.7 & 13.0 \\
\hline Razor blades & 46 & 2.3 & 1.5 & 0.12 & 71.6 & 76.8 & 81.7 & 85.9 & $n a$ & 5.2 & 10.2 & 14.3 \\
\hline Average & 70 & 8.1 & 4.8 & 0.09 & 57.0 & 63.3 & 67.9 & 71.5 & & 6.3 & 10.8 & 14.5 \\
\hline
\end{tabular}

* Mean Average Percentage Error 
The regression results are shown in Table 3 .

\section{Table 3 Regression results}

\begin{tabular}{|c|c|c|c|c|c|c|c|c|}
\hline 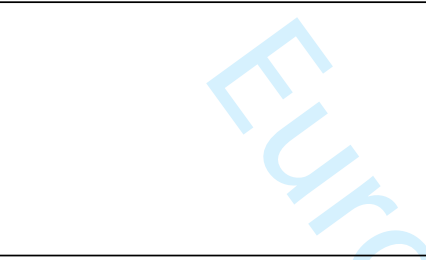 & \multicolumn{4}{|c|}{$\begin{array}{l}\text { Model } 1 \text {. } \\
\text { Only brands that stayed within } 2 \text { points } \\
\text { of commencing market share. } \\
\text { Observations = 684. } \\
\text { Dependent variable: proportion of year } 1 \\
\text { buyers who fail to purchase the brand in } \\
\text { year } 2,3,4,5\end{array}$} & \multicolumn{4}{|c|}{$\begin{array}{l}\text { Model } 2 \text {. } \\
\text { All brands. Observations }=800 \text {. } \\
\text { Dependent variable: proportion of } \\
\text { year } 1 \text { buyers who fail to purchase } \\
\text { the brand in year } 2,3,4,5\end{array}$} \\
\hline R Sq. within & 079 & & & & 078 & & & \\
\hline between & 0.80 & & & & 0.80 & & & \\
\hline overall & 0.79 & & & & 0.78 & & & \\
\hline & Coef. & $\begin{array}{l}\text { Robust } \\
\text { Std. Err. }\end{array}$ & $\mathrm{Z}$ & $\mathrm{P}>|\mathrm{Z}|$ & Coef. & $\begin{array}{l}\text { Robust } \\
\text { Std. } \\
\text { Err. }\end{array}$ & $\mathrm{Z}$ & $\mathrm{P}>|\mathrm{Z}|$ \\
\hline Year $3 * *$ & 0.06 & 0.002 & 40.9 & 0.001 & 0.06 & 0.002 & 40.4 & 0.001 \\
\hline Year 4 & 0.11 & 0.003 & 34.6 & 0.001 & 0.11 & 0.004 & 25.2 & 0.001 \\
\hline Year 5 & 0.14 & 0.004 & 36.5 & 0.001 & 0.14 & 0.004 & 33.4 & 0.001 \\
\hline Brand Penetration & -1.02 & 0.14 & -7.3 & 0.001 & -1.01 & 0.11 & -8.8 & 0.001 \\
\hline Niche Brand & -0.04 & 0.01 & -5.7 & 0.001 & -0.05 & 0.01 & -5.9 & 0.001 \\
\hline Store Brand & -0.06 & 0.03 & -2.5 & 0.014 & -0.07 & 0.03 & -2.3 & 0.023 \\
\hline Promotion Incidence Mfr. Brand & -0.03 & 0.01 & -2.5 & 0.013 & -0.03 & 0.01 & -2.6 & 0.008 \\
\hline Price Promotion depth & 0.001 & 0.01 & -0.1 & 0.929 & -0.006 & 0.00 & -1.3 & 0.194 \\
\hline Brand Price Index* & -0.004 & 0.00 & -1.0 & 0.320 & -0.006 & 0.01 & -1.1 & 0.266 \\
\hline Range Breadth & -0.02 & 0.007 & -3.1 & 0.002 & -0.024 & 0.006 & -4.0 & 0.001 \\
\hline Category Penetration & -0.11 & 0.034 & -3.2 & 0.001 & -0.08 & 0.024 & -3.3 & 0.001 \\
\hline Category Purchase Frequency & 0.002 & 0.001 & 1.8 & 0.071 & 0.003 & 0.001 & 2.1 & 0.032 \\
\hline Constant & 0.86 & 0.025 & 34.6 & 0.001 & 0.85 & 0.020 & 42.4 & 0.001 \\
\hline
\end{tabular}

** Year 2 is the contrast for these yearly dummy variables. *Price index: (smaller index $=$ lower price)

\subsection{Hypothesis testing}

H1 posed that erosion takes place at a constant rate, that is, the rate it occurs at does not diminish over time. In Table 2 we see that on average $57 \%$ of year 1 's brand buyers fail to repurchase the brand in year 2. This figure climbs to $63.3 \%$ in year 3 (an increase of 6.3 ). It climbs again to 67.9 in year 4 (total loss from year 2 of 10.8, an increase of 4.5 from year 3 ).

By year 5, 71.5\% of year 1's buyers fail to re-purchase, which is a total loss from year 2 of 14.5, and between year 4 and 5 a loss of 3.7. Therefore, erosion in years 3,4,5 respectively is $6.3,4.5$, and 3.7 points. The rates are statistically significantly different (each significantly different to the other at $\mathrm{p}<0.05, \mathrm{~F} 16.7$, d.f. 2 using a post-hoc test). Therefore, $\mathrm{H} 1$ is not supported - the rate of erosion diminishes over time. 
Next, to test $\mathrm{H} 2$ we examine the link between erosion and repertoire growth. We first calculated the projected 5-year penetration for each brand by applying the NBD to the base year metrics (Ehrenberg, 1988). We then used the projected penetrations to calculate theoretical repertoire sizes (Trinh, 2014). This calculation produces an estimate of what repertoire sizes would grow to over time if purchase propensities were fixed. We then computed the actual 5-year penetrations and repertoire sizes, and then compared the estimated figures to the actual figures.

We found that actual repertoire size was significantly larger than the NBD-estimated figure, in other words, larger than what would occur if purchase propensities were fixed (actual 4.2, NBD estimate $3.2, \mathrm{p}<0.01$ ). If brand repertoires are larger, then brand penetrations should also be larger than expected over the five-year period. Findings confirmed that brand penetrations over time were larger than expected (mean penetration 0.19 vs. expected 0.15 , $\mathrm{p}<0.01)$. H2 is therefore supported. This finding clarifies the mechanism by which erosion occurs. Erosion for a brand does not mean buyers in a sense 'drop' one brand and confine their purchases to a smaller subset than before, but rather, one brand is dropped and replaced with another, or other brands. The end result is that brands exhibit a larger buyer base over time than would otherwise be the case, but their buyers are also lighter or less frequent, because they are purchasing across a larger brand repertoire.

\subsection{Testing Hypotheses 3 to 7}

To address hypotheses 3 to 7 we utilise the regression models.

$\mathrm{H} 3 \mathrm{a}$ proposed that higher promotion incidence is negatively related to erosion. We found that including promotion incidence and the interaction term (price promotion incidence $\mathrm{x}$ manufacturer brand) rendered both variables non-significant due to collinearity. We retained the interaction term. Table 3 shows the coefficient for this variable is negative and 
statistically significant in the sample of stable brands $(-0.03, \mathrm{p}=0.01)$ and also in the full sample of brands. These results provide partial support for $\mathrm{H} 3 \mathrm{a}$, in that there is evidence price promotion incidence is associated with lower levels of erosion in the buyer base - but only for manufacturer brands, not store brands.

$\mathrm{H} 3 \mathrm{~b}$ proposed that greater depth of price cuts would be negatively related to erosion. However, we see promotion depth is not significant in either model.

H4 posed that niche brands will have lower erosion rates. The models provide support for this hypothesis, with the coefficient for niche brand being negative and statistically significant in the stable sample $(-0.04, \mathrm{p}<0.01)$, with a similar result in the full sample of brands. Therefore, niche brands, with high relative loyalty in terms of current purchase frequency or SCR (Bhattacharya, 1997), also tend to retain their existing customers in subsequent years to a somewhat greater extent.

H5 posed that store brands will have lower rates of erosion. We find support for this hypothesis in the models, with the store brand coefficient being negative and statistically significant (model $1-0.06, \mathrm{p}=0.01$; model $2-0.07, \mathrm{p}=0.02$ ).

H6 relates to low priced-brands. The coefficient for brand price index is non-significant in both of the models. Therefore, there is an absence of evidence that low brand price is associated with lower erosion.

$\mathrm{H} 7$ relates to a larger product range being associated with lower erosion. The coefficient for range breadth is negative and statistically significant in the sample of stable brands $(-0.02$, $\mathrm{p}=0.002)$ and the full sample of brands $(-0.024, \mathrm{p}=0.001)$. Therefore, H7 is supported.

We also note the models show large, negatively signed coefficients for brand penetration (e.g. $-1.0, \mathrm{p}<0.01$ in model 1), indicating brands with larger penetration have lower rates of 
erosion. This variable was not the subject of a hypothesis, but was included as a covariate. The results for this variable support the findings of East \& Hammond (1996): large brands have lower erosion. Next, the coefficient for category penetration is negative and significant in both models, indicating the rate of customer loss over time is lower for brands in categories that a higher proportion of the population buy in a year. Lastly, we find category purchase frequency is positive and significant in both models. This finding suggests erosion is slightly higher for brands in categories that are purchased more frequently. It may be that frequent category purchasing is linked to variety seeking (e.g. Kahn, 1995), leading to replacement of brands in the repertoire over time.

\section{Discussion}

The findings build upon two previous studies (Ehrenberg, 1988, East and Hammond, 1996), not only confirming and clarifying the erosion phenomenon, but identifying several factors that co-vary with it. In addition, the results provide an explanation of how erosion occurs.

It has long been known that of all the buyers who buy a brand in a base period, such as a year, only a proportion will buy the next year. This is simply because many buyers are very 'light' or infrequent (Sharp, 2010) buying at an average rate of less than once per year, so they appear in certain years and not others. However, what we see here is that the proportion of the base year's buyers who return reduces steadily over time, whereas fixed propensity models suggest this proportion should remain stable. More specifically, we find the loss in the base year's customer pool continues, albeit at a declining rate, over multiple years. Moreover, we find that this loss differs systematically according to category, brand and marketing mix factors. While erosion means that for any brand, some of its buyers drop it from their repertoires, this does not mean that those buyers then confine their purchases to a smaller brand set. 
In fact, we see that erosion is linked to larger brand repertoires: buyers of this sample of brands on average had repertoires of approximately one additional brand over a multi-year period than would occur with no erosion; and likewise brands on average had four percentage points larger penetration. The mechanism underlying erosion is therefore that even in equilibrium markets, consumer's propensities to buy a brand are not fixed, rather, they change or drift over time. Therefore, this study contributes to past work on the conceptualisation and measurement of brand purchase propensities (e.g. Fader and Lattin, 1993).

Next, the findings of this study have implications for customer acquisition and retention research. Firstly, this sample of stable brands exhibited significant reductions over time in their base-year buyers; yet they managed to remain stable in market share. This highlights the fact that some degree of erosion (while showing associations with certain covariates, discussed shortly) - is a 'fact of life' for consumer goods brands. The managerial implication is that finding new buyers is not optional, even for a brand with stable market share. The stable brands in our sample have remained so because they have been able to attract enough new, or very infrequent buyers to buy the brand at least occasionally, and have also been able to either (a) replace the buyers 'lost' via erosion, and for some brands, (b) perform somewhat better on lowering the erosion rate, reducing the need to work quite as hard to attract new buyers. Therefore, the beneficial supporting role of retention on brand share maintenance via lower erosion is made more apparent from these findings.

The study also has implications for research on brand growth and marketing metrics. Past work has highlighted that brand growth comes more from acquisition than retention (e.g. Riebe et al., 2014). Related work has also shown brand growth is primarily reflected in higher penetration figures, with little change in loyalty metrics such as purchase frequency or share of wallet (Nenycz-Thiel et al., 2018, Romaniuk et al., 2014). However, an aspect of this 
study provides additional evidence linking loyalty metrics to brand growth. We refer to the correlation matrix of variables in Appendix 2. While we filtered out brands that changed market share by more than two points for model 1, we included the figures for annual market share change in this table for information. We note the bivariate correlation between customer loss and annual brand market share change is negative and significant, $(\mathrm{r}=-0.21$, $\mathrm{p}<0.01)$. This relationship warranted some supplementary analysis, which revealed that the partial correlation between erosion and market share change, controlling for all the variables that were used in the regression model is $r=-0.20, p<0.01$. In other words, brands that grew had lower rates of loss or erosion, and brands that declined had higher rates of such loss controlling for other relevant variables. Therefore, we establish that there is certainly an association not only between erosion and a brand's ability to maintain share, but that erosion levels are linked to brand growth or decline. This provides a useful contribution to the stream of work examining brand growth factors (e.g. Bennett and Graham, 2010, Nenycz-Thiel et al., 2018).

Now we turn to the findings relating to brand or marketing mix factors. There is evidence that higher levels of price promotion (either within brands over time, or across brands) is related to lower erosion in the buyer base. This evidence was, however, confined to manufacturer brands. This finding provides a useful longitudinal perspective on the aftereffects of price promotions. Past work has identified promotions have only temporary effects (Ehrenberg et al., 1994), partly because most buyers have purchased the brand previously (Dawes, 2018); but that a promotion also brings in some lower-propensity buyers who are less likely to buy afterwards at normal price (Shoemaker and Shoaf, 1977). The findings here add to that knowledge by showing that promotions may play a useful role in reminding and reinforcing existing buyer propensities to purchase the brand. This defensive, albeit expensive, activity may allow other activities to more readily produce sales gains. 
Next, the results indicate that niche brands (Jarvis and Goodman, 2005) tend to naturally do somewhat better at retention. Conversely, a brand identified as change-of-pace, i.e. relatively large customer base but low loyalty - Kahn, Kalwani \& Morrison (1988), will require more marketing effort to retain its current buyer base than a brand of the size that is not change-ofpace. This represents useful contextual knowledge for practitioners. In terms of academic contribution, this is the first finding that has linked strictly cross-sectional behavioural loyalty metrics with a longitudinal measure of loyalty, namely over-time retention.

Of interest to retail brand managers and scholars is the finding that store brands have lower rates of customer loss over time - controlling for category and marketing mix factors. The precise reason is unclear. One potential explanation relates to a purchase reinforcement effect from the store brand often being present in many categories. Another may be that store brands still have some particular appeal to value-seeking consumers, who persist with them over time, with this persistence aided by the fact consumers tend to have high first-store loyalty (East et al., 2000).

A broader range, measured as the number of SKUs offered by a brand compared to the category average was also found to be associated with lower erosion. An important way that a brand's range depth is broadened is via new product introductions. While new products are cast as expensive and risky (Steenkamp and Gielens, 2003), these results indicate part of the payoff from engaging in new product development and launch is a better ability to retain current buyers, likely by providing new options to accommodate consumer desire for variety (Kahn, 1995), drawing attention to the brand on shelf, or simply ensuring a broad spectrum of tastes and preferences is being met (Romaniuk and Sharp, 2016 Ch. 8). 
Certain category level factors emerged as significant covariates of erosion, in particular category penetration. Therefore, brands in categories with higher penetration can expect lower rates of erosion in their customer base, all other things being equal. This finding implies brands in low penetration categories have to 'work harder' to keep themselves salient to their current buyer base.

\section{Limitations and Directions for Future Research}

Erosion was suggested to be 'a consistent, pervasive empirical fact ... little related to the other factors studied' (East and Hammond, 1996 p. 169). This study has advanced our knowledge about erosion and the factors that co-vary with it. This advance may pave the way for fruitful future research endeavours.

A limitation of the present study is that data were not available on the full suite of marketing mix activities, such as brand advertising. It is possible that an inability to incorporate advertising (the focal brand, or competitor's) in the study caused endogeneity, in other words the results of the study could be biased due to omitting potential explanatory variables. Examining the relationship between brand advertising and erosion is therefore a prime candidate for further work. Past studies have shown short-term effects of advertising on individual buyers (Jones, 2006, Taylor et al., 2009), as well as short and long-term effects on brand sales (e.g. Dekimpe and Hanssens, 1995b). Advertising is suggested to be a vehicle that works via reminding and nudging buyer's purchase propensities (Ehrenberg et al., 2002). Examining the over-time covariation between advertising spending and brand erosion rates may be an approach to generate new insights into advertising effectiveness. However, such an investigation would require multi-year data on advertising for a large sample of brands.

A large body of literature finds price promotions generally have only short-term sales effects, with little long-term benefits (Ehrenberg et al., 1994, Dawes, 2018). The results here provide 
evidence that price promotions may play a role in preserving the brand's existing buyer base. An avenue for future work is to explore whether certain characteristics of promotions are more strongly linked to this outcome. Such work would be well-warranted given the large sums spent on such promotions (Bogomolova et al., 2017). The potential moderating or mediating effects of factors such as brand size, price, range size, and the breadth of promotions across the range could add to the initial findings from this study.

An intriguing finding relates to lower levels of over-time loss for Store brands. Future research could examine the extent to which this phenomenon is contingent on the multicategory breadth of the retailer's range. Given the rise in store brands, the high level of academic research dedicated to the field, and the investments made in them by retailers (Seenivasan et al., 2015), insights into store brand performance on this longitudinal loyalty metric would be a useful advance.

Finally, the present study identified an important association between erosion and brand market share change: brands that grew had lower erosion; brands that declined had higher erosion. An avenue for future research is to attempt to disentangle the potential chain of cause and effect between erosion and change in market share.

Author names are in alphabetical order. All authors contributed equally to the work. 


\section{References}

Alford, B. L. \& Biswas, A. (2002), "The effects of discount level, price consciousness and sale proneness on consumers' price perception and behavioral intention", Journal of Business Research, 55, 9, 775-783

Allenby, G. M. \& Lenk, P. J. (1995), "Reassessing brand loyalty, price sensitivity, and merchandising effects on consumer brand choice", Journal of Business and Economic Statistics, 13, 3, 281-89

Ambler, T., Braeutigam, S., Stins, J., Rose, S. \& Swithenby, S. (2004), "Salience and Choice: Neural Correlates of Shopping Decisions", Psychology \& Marketing, 21, 4, 247-261

Ataman, M. B., Mela, C. F. \& Van Heerde, H. J. (2008), "Building Brands", Marketing Science, 27, 6, 1036-1054

Ataman, M. B., Van Heerde, H. J. \& Mela, C. F. (2010), "The long-term effect of marketing strategy on brand sales", Journal of Marketing Research, 47, 5, 866-882

Baldinger, A. L. \& Rubinson, J. (1996), "Brand Loyalty: The Link Between Attitude and Behavior", Journal of Advertising Research, 36, November/December, 22-34

Bandyopadhyay, S. \& Martell, M. (2007), "Does attitudinal loyalty influence behavioral loyalty? A theoretical and empirical study", Journal of Retailing and Consumer Services, 14, 1, 35-44

Banelis, M., Riebe, E. \& Rungie, C. (2013), "Empirical evidence of repertoire size", Australasian Marketing Journal, 21, 1, 59-65

Bennett, D. \& Graham, C. (2010), "Is loyalty driving growth for the brand in front? A twopurchase analysis of car category dynamics in Thailand", Journal of Strategic Marketing, 18, 7, 573-585

Bhattacharya, C. B. (1997), "Is Your Brand's Loyalty Too Much, Too Little, or Just Right? Explaining Deviations in Loyalty from the Dirichlet Norm", International Journal of Research in Marketing, 14, 5, 421-435

Bhattacharya, C. B., Fader, P. S., Lodish, L. M. \& Desarbo, W. S. (1996), "The Relationship Between the Marketing Mix and Share of Category Requirements", Marketing Letters, 7, 1, 5-18

Bijmolt, T. H. A., Van Heerde, H. J. \& Pieters, R. G. M. (2005), "New empirical generalizations on the determinants of price elasticity", Journal of Marketing Research, XLII, May, 141-156

Bogomolova, S., Dunn, S., Trinh, G., Taylor, J. \& Volpe, R. J. (2015), "Price promotion landscape in the US and UK: Depicting retail practice to inform future research agenda", Journal of Retailing and Consumer Services 25, 7, 1-11

Bogomolova, S., Szabo, M. \& Kennedy, R. (2017), "Retailers' and manufacturers' pricepromotion decisions: Intuitive or evidence-based?", Journal of Business Research, 76, $1,189-200$

Bolton, R. N. (1989), "The Relationship Between Market Characteristics and Promotional Price Elasticities", Marketing Science, 8, 2, 153-169

Cameron, A. C. \& Trivedi, P. K. (2010), Microeconometrics Using Stata, Stata Press, College Station, Texas, United States.

Casteran, G., Chrysochou, P. \& Meyer-Waarden, L. (2019), "Brand Loyalty Evolution and the Impact of Category Characteristics", Marketing Letters,

Castleberry, S. B., Barnard, N. R., Barwise, T. P., Ehrenberg, A. \& Dall'olmo Riley, F. (1994), "Individual Attitude Variations Over Time", Journal of Marketing Management, 10, 1-3, 153-162 
Chatfield, C., Ehrenberg, A. \& Goodhardt, G. (1966), "Progress on a simplified model of stationary purchasing behaviour", The Journal of the Royal Statistical Society, 129, 3, 317-367

Dall'olmo Riley, F., Ehrenberg, A., Castleberry, S. B., Barwise, T. P. \& Barnard, N. R. (1997), "The variability of attitudinal repeat-rates", International Journal of Research in Marketing, 14, 5, 437-450

Dawes, J. (2013), "Reasons for variation in SCR for private label brands", European Journal of Marketing, 47, 11/12, 1804-1824

Dawes, J. (2014), "Cigarette brand loyalty and purchase patterns: an examination using US consumer panel data", Journal of Business Research, 67, 9, 1933-1943

Dawes, J., Bond, A., Hartnett, N. \& Sharp, B. (2017), "Does Double Jeopardy apply using Average Spend Per Buyer as the Loyalty Metric?", Australasian Marketing Journal $25,261-268$

Dawes, J., Meyer-Waarden, L. \& Driesener, C. (2015), "Has brand loyalty declined? A longitudinal analysis of repeat purchase behavior in the UK and the USA", Journal of Business Research, 68, 2, 425-432

Dawes, J. G. (2018), "Price promotions: examining the buyer mix and subsequent changes in purchase loyalty", Journal of Consumer Marketing, 35, 4, 366-376

De Wulf, K., Odekerken-Schröder, G., Goedertier, F. \& Van Ossel, G. (2005), "Consumer perceptions of store brands versus national brands", Journal of Consumer Marketing, $22,4,223-232$

Dekimpe, M. G. \& Hanssens, D. M. (1995a), "Empirical Generalizations About Market Evolution and Stationarity", Marketing Science, 14, No. 3, Part 2, G109-G121

Dekimpe, M. G. \& Hanssens, D. M. (1995b), "The persistence of marketing effects on sales", Marketing Science, 14, 1, 1-21

Dick, A. S. \& Basu, K. (1994), "Customer Loyalty: Toward an Integrated Conceptual Framework", Journal of the Academy of Marketing Science, 22, No. 2, 99-113

East, R. \& Hammond, K. (1996), "The Erosion of Repeat-Purchase Loyalty", Marketing Letters, 7, 2, 163-171

East, R., Hammond, K., Harris, P. \& Lomax, W. (2000), "First-store loyalty and retention", Journal of Marketing Management, 16, 4, 307-325

East, R., Wright, M. \& Vanhuele, M. (2008), Consumer Behaviour: Applications in Marketing, Sage, London.

Ehrenberg, A. (1959), "The pattern of consumer purchases", Applied Statistics, 8, 1, 26-41

Ehrenberg, A. (1988), Repeat-buying: Facts, theory and applications, Oxford University Press, London.

Ehrenberg, A. (2000), "Repeat-buying: facts, theory and applications", Journal of Empirical Generalisations in Marketing Science, 5, 2, 392-770

Ehrenberg, A., Barnard, N., Kennedy, R. \& Bloom, H. (2002), "Brand advertising as creative publicity", Journal of Advertising Research, 42, 4, 7-18

Ehrenberg, A., Goodhardt, G. \& Barwise, T. P. (1990), "Double Jeopardy revisited", Journal of Marketing, 54, 3, 82-91

Ehrenberg, A., Hammond, K. \& Goodhardt, G. J. (1994), "The After-Effects of price-related consumer promotions", Journal of Advertising Research, 34, 4, 11-21

Ehrenberg, A., Uncles, M. D. \& Goodhardt, G. G. (2004), "Understanding brand performance measures: using dirichlet benchmarks", Journal of Business Research, 57, 12, 1307 1325

Evanschitzky, H., Malhotra, N., Wangenheim, F. V. \& Lemon, K. N. (2017), "Antecedents of Peripheral Services Cross-Buying Behavior", Journal of Retailing and Consumer Services, 36, 1, 218-224 
Fader, P. \& Lattin, J. M. (1993), "Accounting for Heterogeneity and Nonstationarity in a Cross-Sectional Model of Consumer Purchase Behavior", Marketing Science, 12, No. 3, Summer, 304-317

Fader, P. S. \& Schmittlein, D. C. (1993), "Excess behavioral loyalty for high-share brands: deviations from the Dirichlet model for repeat purchasing", Journal of Marketing Research, 30, 4, 478-493

Farris, P., Bendle, N., Pfeifer, P. E. \& Reibstein, D. J. (2016), Marketing metrics: The manager's guide to measuring marketing performance, Pearson, New Jersey, United States.

Givon, M. \& Horsky, D. (1990), "Untangling the effects of purchase reinforcement and advertising carryover", Marketing Science, 9, 2, 171-187

Goodhardt, G. \& Ehrenberg, A. (1967), "Conditional trend analysis: A breakdown by initial purchasing level", Journal of Marketing Research, 4, May, 155-161

Goodhardt, G. J., Ehrenberg, A. \& Chatfield, C. (1984), "The Dirichlet: A comprehensive model of buying behaviour", Journal of the Royal Statistical Society, 147, 5, 621-655

Graham, C., Bennett, D., Franke, K., Henfrey, C. L. \& Nagy-Hamada, M. (2017), "Double Jeopardy-50 years on. Reviving a forgotten tool that still predicts brand loyalty", Australasian Marketing Journal (AMJ), 25, 4, 278-287

Graham, C. D. A. (2009), "What's the point of Marketing anyway? The prevalence, temporal extent and implications of long-term market share equilibrium", Journal of Marketing Management, 25, 9-10, 867-874

Greene, W. H. (2011), Econometric analysis, Prentice hall Upper Saddle River, NJ.

Grewal, D., Monroe, K. B. \& Krishnan, R. (1998), "The effects of price-comparison advertising on buyers' perceptions of acquisition value, transaction value, and behavioral intentions", The Journal of Marketing, 62, 2, 46-59

Habel, C., Rungie, C., Geursen, G. \& Kweh, J., (2003), "Common ground for Bass and NBD/Dirichlet: is conditional trend analysis the bridge?", ANZMAC: Australian \& New Zealand Marketing Academy Conference, Adelaide,

Hair, J. F., Anderson, R. E., Tatham, R. L. \& Black, W. C. (1995), Multivariate Data Analysis, Prentice Hall International, New Jersey.

Hoch, S. J., Kim, B.-D., Montgomery, A. L. \& Rossi, P. E. (1995), "Determinants of StoreLevel Price Elasticity", Journal of Marketing Research, 32, February, 17-29

Hyman, M. R., Kopf, D. A. \& Lee, D. (2010), "Review of literature-Future research suggestions: Private label brands: Benefits, success factors and future research", Journal of Brand Management, 17, 5, 368-389

Jarvis, W. \& Goodman, S. (2005), "Effective marketing of small brands: niche positions, attribute loyalty and direct marketing", Journal of Product \& Brand Management, 14, $5,292-299$

Jones, J. P. (2006), When ads work: New proof that advertising triggers sales, M.E. Sharpe, Inc, New York.

Jung, S., Gruca, T. \& Lopo, R. (2010), "Excess loyalty in CPG markets: a comprehensive examination", Journal of Empirical Generalisations in Marketing Science, 13, 1, 1-13

Kahn, B. (1995), "Consumer variety-seeking among goods and services:: An integrative review", Journal of Retailing and Consumer Services, 2, 3, 139-148

Kahn, B. E., Kalwani, M. U. \& Morrison, D. G. (1986), "Measuring Variety-Seeking and Reinforcement Behaviors Using Panel Data", Journal of Marketing Research, 23, May, 89-100

Kahn, B. E., Kalwani, M. U. \& Morrison, D. G. (1988), "Niching versus change-of-pace brands: Using purchase frequencies and penetration rates to infer brand positionings", Journal of Marketing Research, 25, 4, 384-390 
Kalwani, M. U., Yim, C. K., Rinne, H. J. \& Sugita, Y. (1990), "A Price Expectations Model of Customer Brand Choice", Journal of Marketing Research, 27, August, 251-262

Keane, M. P. (1997), "Modeling heterogeneity and state dependence in consumer choice behavior", Journal of Business \& Economic Statistics, 310-327

Keller, W. I. Y., Deleersnyder, B. \& Gedenk, K. (2019), "Price Promotions and Popular Events", Journal of Marketing, 83, 1, 73-88

Kumar, N. \& Steenkamp, J.-B. E. M. (2007), Private label strategy: How to meet the store brand challenge, Harvard Business Press, US.

Kumar, V., Dalla Pozza, I. \& Ganesh, J. (2013), "Revisiting the satisfaction-loyalty relationship: empirical generalizations and directions for future research", Journal of Retailing, 89, 3, 246-262

Lam, D. \& Mizerski, R. (2009), "An investigation into gambling purchases using the NBD and NBD-dirichlet models", Marketing Letters, 20, 3, 263-276

Lattin, J. M. \& Bucklin, R. E. (1989), "Reference Effects of Price and Promotion on Brand Choice Behavior", Journal of Marketing Research, 26, August, 299-310

Lee, R., Rungie, C. \& Wright, M. (2011), "Regularities in the consumption of a subscription service", Journal of Product \& Brand Management, 20, 3, 182-189

Lenk, P. J., Rao, A. G. \& Tibrewala, V. (1993), "Nonstationary Conditional Trend Analysis: An Appplication to Scanner Panel Data", Journal of Marketing Research, 30, August, 288-304

Lodish, L. M. \& Mela, C. F. (2007), "If brands are built over years, why are they managed over quarters?", Harvard Business Review, 85, 7/8, 104-112

Ludwichowska, G., Romaniuk, J. \& Nenycz-Thiel, M. (2017), "Systematic response errors in self-reported category buying frequencies", European Journal of Marketing, 51, 7/8, 1440-1459

Macé, S. \& Neslin, S. A. (2004), "The determinants of pre- and postpromotion dips in sales of frequently purchased goods", Journal of Marketing Research, 31, August, 339-350

McAlister, L. \& Pessemier, E. (1982), "Variety Seeking Behavior: An Interdisciplinary Review", Journal of Consumer Research, 9, December, 311-322

McCabe, J. \& Stern, P. (2009), "Stochastic modelling and industrial networks complementary views of organisational buyer behavior", Journal of the Academy of Marketing Science, 37, 2, 204-214

Mizerski, D., Miller, R., Mizerski, K. \& Lam, D. (2004), "The stochastic nature of purchasing a State's Lottery products", Australasian Marketing Journal, 12, 3, 56-69

Morrison, D. G. (1969), "Conditional trend analysis: A model that allows for nonusers", Journal of Marketing Research, VI, August, 342-6

Nenycz-Thiel, M., Dawes, J. \& Romaniuk, J. (2018), "Modeling Brand Market Share Change in Emerging Markets", International Marketing Review, 1-40

Nogales, A. F. \& Suarez, M. G. (2005), "Shelf space management of private labels: a case study in Spanish retailing", Journal of Retailing and Consumer Services, 12, 3, 205 216

Pare, V. \& Dawes, J. (2011), "The persistence of excess brand loyalty over multiple years", Marketing Letters, 21, 2, 163-175

Reichheld, F. F. (1993), "Loyalty-based management", Harvard Business Review, 71, 2, 6473

Riebe, E., Wright, M., Stern, P. \& Sharp, B. (2014), "How to grow a brand: Retain or acquire customers?", Journal of Business Research, 67, 5, 990-997

Romaniuk, J., Dawes, J. \& Nenycz-Thiel, M. (2014), "Generalizations regarding the growth and decline of manufacturer and store brands", Journal of Retailing and Consumer Services, 21, 5, 725-734 
Romaniuk, J. \& Sharp, B. (2016), How brands grow: Part 2, Oxford University Press, South Melbourne.

Sayman, S. \& Raju, J. S. (2004), "Investigating the cross-category effects of store brands", Review of Industrial Organization, 24, 129-141

Schmittlein, D. C., Cooper, L. G. \& Morrison, D. G. (1993), "Truth in Concentration in the Land of (80/20) Laws", Marketing Science, 12, 2, 167-183

Scriven, J., Clemente, M., Dawes John, Trinh, G. \& Sharp, B. (2017), "Buying Brands at both Regular Price and on Promotion Over Time ", Australasian Marketing Journal 25, 4, 252-260

Seenivasan, S., Sudhir, K. \& Talukdar, D. (2015), "Do store brands aid store loyalty?", Management Science, 62, 3, 802-816

Sethuraman, R. (1996), "A Model of How Discounting High-Priced Brands Affects the Sales of Low-Priced Brands", Journal of Marketing Research, 33, November, 399-409

Sethuraman, R. \& Cole, C. (1999), "Factors influencing the price premiums that consumers pay for national brands over store brands", Journal of Product and Brand Management, 8, 4, 340-351

Sethuraman, R. \& Srinivasan, V. (2002), "The asymmetric share effect: An empirical generalization on cross-price effects", Journal of Marketing Research, 39, 3, 379-386

Sethuraman, R., Srinivasan, V. \& Kim, D. (1999), "Asymmetric and Neighborhood CrossPrice Effects: Some Empirical Generalizations", Marketing Science, 18, No. 1, 23-41

Sharp, B. (2010), How Brands Grow, Oxford University Press, South Melbourne.

Sharp, B., Wright, M., Dawes, J., Driesener, C., Meyer-Waarden, L., Stocchi, L. \& Stern, P. (2012), "It's a Dirichlet world: Modeling individuals' loyalties reveals how brands compete, grow, and decline", Journal of Advertising Research, 52, 2, 203-213

Shoemaker, R. W. \& Shoaf, F. R. (1977), "Repeat Rates of Deal Purchases", Journal of Advertising Research, 17, 2

Steenkamp, J. B. E. M. \& Gielens, K. (2003), "Consumer and market drivers of the trial probability of new consumer packaged goods", Journal of Consumer Research, 30, 3, 368-384

Swait, J. \& Adamowicz, W. (2001), "The influence of task complexity on consumer choice: A latent class model of decision strategy switching", Journal of Consumer Research, 28, $1,135-148$

Tanusondjaja, A., Nenycz-Thiel, M., Dawes, J. \& Kennedy, R. (2018), "Portfolios: Patterns in brand penetration, market share, and hero product variants", Journal of Retailing and Consumer Services, 41, 211-217

Tanusondjaja, A., Trinh, G. \& Romaniuk, J. (2016), "Exploring the past behaviour of new brand buyers", International Journal of Market Research, 58, 5, 733-748

Taylor, J., Kennedy, R. \& Sharp, B. (2009), "Is Once Really Enough? Making Generalizations about Advertising's Convex Sales Response Function", Journal of Advertising Research, 49, 2, 198-200

Ter Braak, A., Geyskens, I. \& Dekimpe, M. G. (2014), "Taking private labels upmarket: Empirical generalizations on category drivers of premium private label introductions", Journal of Retailing, 90, 2, 125-140

Trinh, G. (2014), "Predicting variation in repertoire size with the NBD model", Australasian Marketing Journal, 22, 2, 111-116

Trinh, G. \& Lam, D. (2016), "Understanding the attendance at cultural venues and events with stochastic preference models", Journal of Business Research, 69, 9, 3538-3544

Uncles, M. D. \& Ellis, K. (1989), "The Buying of Own Labels", European Journal of Marketing, 23, No. 3, 47-70 
Wilkinson, J. W., Trinh, G., Lee, R. \& Brown, N. (2016), "Can the negative binomial distribution predict industrial purchases?", Journal of Business and Industrial Marketing, 31, 4, 543-552

Wooldridge, J. M. (2015), Introductory Econometrics: A Modern Approach (Upper Level Economics Titles) South-Western College Pub, United States.

Zeithaml, V. A. (1988), "Consumer perceptions of price, quality, and value: A means-end model and synthesis of evidence", The Journal of Marketing, 52, 3, 2-22 
Appendix: Descriptive statistics and correlation matrix of variables (all brands).

\begin{tabular}{|c|c|c|c|c|c|c|c|c|c|c|c|c|c|c|c|}
\hline & & Mean & $\begin{array}{c}\text { Std } \\
\text { Dev. }\end{array}$ & 1 & 2 & 3 & 4 & 5 & 6 & 7 & 8 & 9 & 10 & 11 & 12 \\
\hline Customer Loss & 1 & 0.65 & 0.15 & 1 & $-.723^{* *}$ & $-.440^{* *}$ & $.106^{* * *}$ & $-.331 * *$ & $-.102^{* *}$ & $-.076^{*}$ & $-.550 * *$ & $-.390^{* *}$ & $-.411^{* * *}$ & $.432 * *$ & $211^{* *}$ \\
\hline Brand penetration & 2 & 0.08 & 0.09 & $-.723 * *$ & 1 & $.087^{*}$ & $-.373^{* * *}$ & $.502^{* * *}$ & $.147^{* *}$ & 0.053 & $.684^{* * *}$ & $.387^{* *}$ & $.388^{* *}$ & $.410^{* *}$ & $.121^{* *}$ \\
\hline Niche brand & 3 & 2.39 & 0.80 & $-.440^{* * *}$ & $.087^{*}$ & 1 & $.255^{* * *}$ & $-.117^{* *}$ & 0.035 & 0.016 & 0.046 & $.369^{* *}$ & $.255^{* *}$ & $.305^{* *}$ & $.104 *$ \\
\hline Store brand & 4 & 0.48 & 0.50 & $.106^{* *}$ & $-.373^{* *}$ & $.255^{* *}$ & 1 & $-.534 * *$ & $-.231^{* *}$ & $-.119^{* *}$ & $-.237 * *$ & $-.132^{* *}$ & $-.093 * *$ & $.136^{* *}$ & -0.047 \\
\hline Promotion incidence & 5 & 0.35 & 0.26 & $-.331 * *$ & $.502 * *$ & $-.117 * *$ & $-.534 * *$ & 1 & $.304 * *$ & $.119^{* * *}$ & $.343 * *$ & $.316^{* *}$ & $.224 * *$ & $.319^{* *}$ & 0.018 \\
\hline Promotion depth & 6 & 0.08 & 0.48 & $-.102 * *$ & $.147^{* * *}$ & 0.035 & $-.231^{* *}$ & $.304 * *$ & 1 & 0.04 & $.130^{* *}$ & $.152^{* *}$ & $.117^{* *}$ & $.144 * *$ & -0.003 \\
\hline Brand price & 7 & 9.17 & 15.7 & $-.076^{*}$ & 0.053 & 0.016 & $-.119^{* *}$ & $.119^{* *}$ & 0.04 & 1 & $.298 * *$ & $-.126^{* *}$ & $.098 * *$ & $.097 * *$ & -0.008 \\
\hline Range breadth & 8 & 23.7 & 24.3 & $-.550^{* * *}$ & $.684 * *$ & 0.046 & $-.237 * *$ & $.343^{* *}$ & $.130^{* *}$ & $.298 * *$ & 1 & $.115^{* *}$ & $.142^{* *}$ & $.146^{* * *}$ & 0.036 \\
\hline Category purchase rate & 9 & 8.19 & 3.91 & $-390^{* * *}$ & $.387^{* * *}$ & $.369^{* *}$ & $-.132^{* * *}$ & $.316^{* * *}$ & $.152^{* * *}$ & $-.126 * *$ & $.115^{* * *}$ & 1 & $.648^{* *}$ & $.972 * *$ & 0.021 \\
\hline Category penetration & 10 & 0.69 & 0.22 & $-411^{* *}$ & $.388 * *$ & $.255^{* *}$ & $-.093^{* *}$ & $.224 * *$ & $.117^{* *}$ & $.098 * *$ & $.142^{* *}$ & $.648 * *$ & 1 & $.724 * *$ & 0.056 \\
\hline Repertoire size & 11 & 2.19 & 0.63 & $-.432 * *$ & $.410^{* * *}$ & $.305^{* *}$ & $-.136^{* * *}$ & $.319^{* *}$ & $.144 * *$ & $-.097 * *$ & $.146^{* * *}$ & $.972^{* *}$ & $.724 * *$ & 1 & 0.023 \\
\hline Market share change** & 12 & 0.01 & 0.01 & $-.211^{* *}$ & $.121 * *$ & $.104 *$ & -0.047 & 0.018 & -0.003 & -0.008 & 0.036 & 0.021 & 0.056 & 0.023 & 1 \\
\hline
\end{tabular}

$*=$ sig. at $\mathrm{p}<=0.05 * *$ sig. at $\mathrm{p}<=0.01 \quad * * *$ note, brands that changed market share by more than two points over the period were omitted from model 1 but retained as a robustness check in model 2. 